\title{
RECREATION CAPACITY OF UKRAINE'S REGIONS, STRATEGIC GOALS OF ITS USAGE AND BUILDING
}

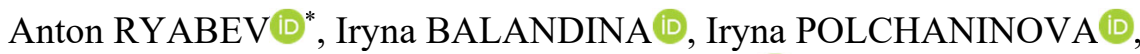 \\ Larysa OBOLENTSEVAD \\ Department of Tourism and Hospitality, Faculty of Management, \\ O.M. Beketov National University of Urban Economy in Kharkiv, 61002, \\ Marshal Bazhanov Street, 17, Kharkiv, Ukraine \\ *E-mail: kharkov-kruiz@mail.ru
}

\begin{abstract}
Purpose - to reveal the scientific approach to the regional policy in the field of research, use and increase the recreational potential of the regions of Ukraine, creating an effective mechanism for the development of the recreational system of the region due to an in-depth study of the recreational system potential, the quality of the recreational environment and highlighting its special structure. As a sub-goal of the study was determined the identification of factors affecting the competitiveness of the recreational system of the regions, which will make it possible to clarify the directions of activities to increase the competitiveness of the tourism and recreation sector of the economy of Ukraine.

Findings - the paper proposes the mechanism of well-balanced mutual development of human's health and recreational system management.

Research limitations - the study addresses the problem of using recreational potential in such a way that, as a result of its use, the least damage is inflicted on the territory and on the population. To determine the direction of development were identified as "sore spots" groups of the recreational system. To solve this problem has been proposed a mechanism for the balanced development of the recreational system, which will allow: 1) to maintain and develop the existing recreational potential; 2) to increase the share of regional profits from the use of recreational potential.
\end{abstract}

Methodology - the methodology and research tools are based on the methods of theoretical generalization, refinement of the conceptual apparatus, logical-structural modelling, scientific argumentation, and comparative analysis.

Practical implications - the practical significance lies in the fact that the article reveals the problematic issues of recreation in Ukraine and suggests a mechanism for the management and sustainable development of the country's recreational potential. The use of the proposed mechanism will lead to an increase in the incomes of the regions from the exploitation of the recreational potential and will create the conditions for the preservation of the recreational systems themselves.

Originality/Value - the article value lies in the fact that it proposes a mechanism for the balanced development of the recreational system and the person in it; carried out the allocation of recreational management in a special function of the recreational system. The relationship between the development strategies of the recreational system and the assessment of the recreational competitiveness of the region is shown.

Keywords: recreation capacity, recreational management, recreational system.

JEL Classification: O29, O52, L83, Q26.

Conference topic: Contemporary Issues in Economics Engineering.

\section{Introduction}

Ukraine has a multi-faceted complex of recreational resources with effective use of which the contribution of this capacity into the country's economy could be doubled or even tripled.

The European natural landscape, mountain range system of Carpathians, numerous architectural and historic monuments, thousand kilometers of the Black Sea's coastline, special national colour, plenty of reserve areas, unique cultural heritage are presented in Ukraine in full scale and can play a role of a pulling power (attractors) not only for its citizens, but also for foreign tourists.

It would be wrong to say that in Ukraine recreational resources are not used, but there are no doubts that this national wealth is used extremely insufficiently and ineffectively. Today, for such a statement there are more than enough estimations and facts. The contribution of tourism to the GDP does not exceed $2 \%$, while in other countries 
(with similar recreation capacity), such as Poland, Bulgary, France, and Germany this contribution is 5-9\% (Dobush, 2013; Fomenko, 2007). But being equal to Ukraine on recreational potential France and Germany are among the top ten destinations for tourism (UNWTO, 2017; Kishor, 2019). The health of the nation and recreation put this function of social development on the first place, is "at the end of the rating" among European countries; the ecological situation on the territory of Ukraine is also estimated beyond required international standards. All of this demonstrates that there is a serious problem with its "sore spots", and that a solution to this problem is vital socially and benefit economically. It is beneficial because the recreational area of activities is one of the most effective for capital investments: the increase of income (and profit) per units of capital invested in this area is 2-3 times bigger than in transport, mechanic engineering, or agriculture (Hall \& Page, 2006; Stupen, 2017).

By using the term "sore spots" we show that recreation and recreational economy should be treated as a living organism, in other words, it should be treated as a system of complex elements, reflexive system which has a controversy of internal relations and characteristics of adaptivity.

In our interpretation, a recreation system is susceptible to diseases (strains, overloads, borderline states, crisis), and that is why a search of means and ways of support of recreational systems in a favourable regime of functioning is necessary, and, ideally, it has to provide their development. In this aspect, in our topic "recreational policy and activities" we deal with a certain phenomenon of duality: from one side recreational environment is a productive economic factor for people and their health, from the other - a person and society must restore the health (sanitize) of the recreational environment (system) itself, in other words it is appropriate to tell that we must realize "recreation of a recreational system" because "polluted, unhealthy" environment and low-effective recreational activities are not able to fulfil the tasks of recovery and support of local inhabitants' and coming tourists' health.

Nature and landscape side of recreational systems is diverse by the status of the territories themselves: these are national nature parks, regional landscape parks, biosphere reserves, monuments of gardening architecture, zoos, arboretums, open-air museums, reconstructed models of retro complexes with restoring of crafts, living conditions, and national colours. In scientific literature, this variety is described as a system of attractors (objects of special interest) or modules. What is more, the notion "recreational module" has a broader meaning, because it can be a tourist, recreational, cultural and educational, economic or infrastructure module etc. And, whole this complex of interconnected blocks is in constant development. However, this development often occurs spontaneously when all main changes proactively arise within a recreational system. All in all, it is not a drawback, but the task is to form both on state and regional levels the mechanism of a well-balanced development of a recreational system.

\section{Recreational system}

In addition, it is necessary to involve public representatives (guides) of the future recreational system products, services and technologies consumers' inquiries for the recreational system development strategy (Karyi, 2015). It is also believed that the conditions for sustainable development should be formed at the state level (UNEP and UNWTO, 2005; Local Government NSW, n.d.).

In our studies (according to the situation in Ukraine), a human being (a group, local society) is considered not only from the perspective of a consumer of recreational services, i.e. for improvement of his/her health, but from the perspective of responsibility for the state of a recreational system which implies his/her participation in enhancement and modernization of recreational systems in areas of living (Figure 1).

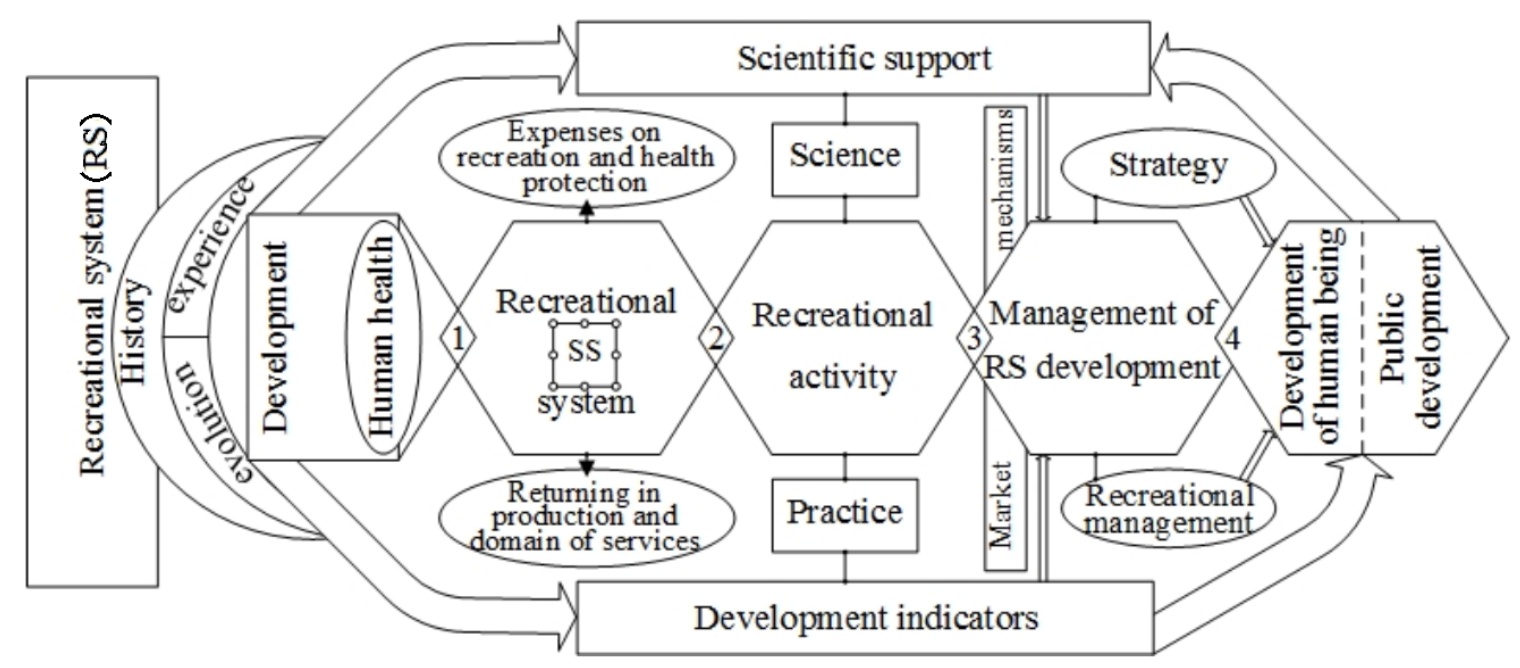

Figure 1. The mechanism of well-balanced mutual development of human's health and recreational system 
Figure 1 demonstrates that a recreational system has a whole complex of components including health (both of a human being and recreational system), economy (economic activities), management of state and development (tools, market mechanisms), productivity (profit from investments). In an integrated manner all structural components of a recreational system, results of its impact on people, economic activities in a recreational system and strategy of its development are included in the functions of the Recreational Management (RM). Certain elements of the RM have been known for a long time, but as a systematic mechanism and economic function, such management has been just forming on a regional level.

Recreational Management has not only one function (economic) but many others. The second function cares about recreation environment itself.

Recreation as a restoration of human health is the most used (acceptable) position of understanding of the notion "recreation" (Stafiichuk, 2008; Pokolodna \& Polchaninova, 2012). But, now, in our time, human health improvement takes place (involuntarily) in unhealthy (degraded) nature and landscape environment: contaminated soils, harmful substances in air, waters (natural and within the systems of water supply), noises and streams of electron irradiation, radiation etc. So, in such a situation the notion "recreation" should be understood in a broader way as a recreation of both human being and environment. Thus, it turns out that a statement "recreation of recreational resources, recreational territories, certain objects of the recreational system" has a right to exist.

Having studied the situation in the country, we can state that Ukraine is a great country with a unique nature, architectural historic monuments, and a variety of picturesque landscapes. In our country, every region is unique and beautiful in its own way. And at the same time, all of them are rundown, not formed, far from being perfect from the perspective of recreation, cultural entertainment, and health improvement.

"Sore spots" of a recreational system can be selected and grouped in three bases: human and the natural ecological environment and human $\left(\mathrm{B}_{1}\right)$, awareness of the situation $\left(\mathrm{B}_{2}\right)$, and organization of recreational activities $\left(\mathrm{B}_{3}\right)$ (Figure 2).

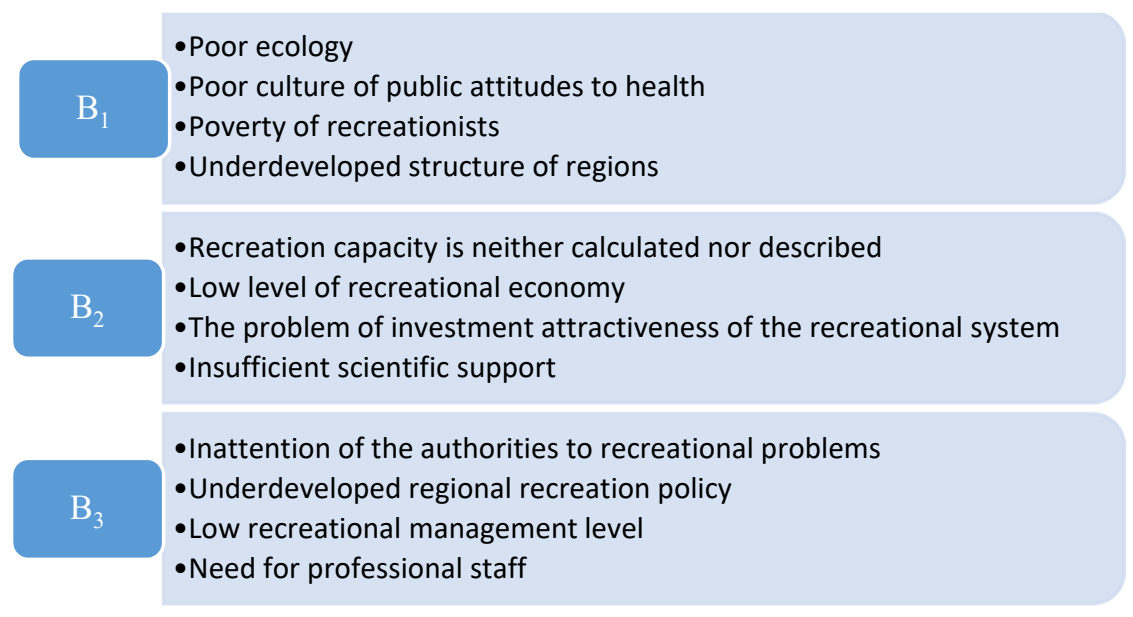

Figure 2. Grouping of the recreational system "sore spots"

"Sore spots" are identified based on the analysis of arguments and assessments of scientific research in Ukraine (Bulysheva \& Andreev, 2018; Gerasimenko, Bedradina, Galasyuk et al., 2016; Poida-Nosyk \& Grabar, 2016; Maister \& Dombrovskaya, 2017; Pavlova, 2016; Dutchak, 2014; Kilinskaya, Anipko, Konovalova, Andrusyak et al., 2010; Gaman, 2008), as well as our own author's research on recreation in the Kharkiv region (Polchaninova \& Tamchy, 2016; Polchaninova \& Perederij, 2015; Polchaninova \& Ignatova, 2011).

The logic of grouping factors into groups $\mathrm{B}_{1}, \mathrm{~B}_{2}, \mathrm{~B}_{3}$ comes from such considerations:

- the ecological environment and recreants should be considered as an integral system, where both components are closely related $\left(\mathrm{B}_{1}\right)$;

- any system (a production or a service sector) is an economic object that requires assessments, analysis and forecast, therefore practical economics and economics are an integral element of the recreational policy mechanism $\left(\mathrm{B}_{2}\right)$;

- for a long period in Ukraine, the processes of recreational development have not been introduced into the regional management regime, and individual non-system measures cannot solve the problem. We need recreational management in the whole hierarchy of the management system from the state level to a specific region $\left(\mathrm{B}_{3}\right)$.

Thus, critical situation of the recreational system appears at a concentration in several sectors: ecological (ecological safety), economic (low profitability and competitive strength of business), infrastructure (underdevelopment of transport and road networks, and services), recreational itself (poor service and staff). It is worth mentioning that the recreational capacity of regions is lowered due to air pollution (industries, motor transport, burning of household wastes), natural waters pollution (IV and V quality classes) and territories pollutions (700 tonnes of waste a year per every Ukraine's citizen; landfills occupy 
up to 7\% of the country's territory), agricultural lands are polluted by chemicals (Informator, 2017; 112.UA., 2016). The result of deterioration of the ecological situation is reflected in the health of the population: due to a poor ecological situation the disease and death rates in Ukraine have reached menacing proportions. Consequently, for the recreation of both the environment and people not only certain measures are needed but drastic programmes on the realization of which the state, region, and general public must work constantly together.

\section{The ways of recreational system development}

Recreational resources and recreation state policy are considered as a growth production factor and services in different fields of activities (in tourism, hotel business, industry etc.). And, this factor is equally important as human health is a factor of labour activity. And this factor has high significance as human health, in general, is a factor in ensuring economic processes.

In respect of economy nature and recreation resources can be evaluated: by a fraction of total income from recreational activity in the whole economic income of the area (income from tourism, hospitality industry, health centers, recreation centers, companies providing additional services in the field of recreation), indicators of cadastral value of recreational resources, coefficient of capacity use, enterprise (organization) profitability coefficient in the field of recreational activities and investment returns in the field of recreation.

A regulator in a recreational system should be a practice of "rationing" according to which fixed design parameters of "edge states" in the use of recreational resources and "reparation of damages" the in a case of damage to a recreational system.

The economic component of a recreational system includes volumes of operational and capital expenses on its maintaining in normative parameters and expenditures on its development.

In modern conditions, economists consider a recreational system as a market object with all its main characteristics: the need for rest and recreation, prices, tariffs, costs as components of a market mechanism, competitiveness of a recreational system, investment opportunity, demand for recreational services of the area and outer markets etc.

Economic science and practice are aimed at providing an efficient use and development of a recreational system of a region (Ryabev \& Balandina, 2017). The first condition is to provide non-controversial interaction of different interested forces and subjects of management of recreational activities development.

There are two different ways of providing the development of the recreational system of a region. The first includes an increase in a number of resources for development (material, financial, informational, intellectual), creation and use of the organizational and economic mechanism of development management. This is the path of rationing and application of forces that provide impetus to development, activating growth points: a direct path. This is the way of "pumping" and application of forces providing the impetus and actuating growth spots: a direct way. The second way is less expensive and in a majority of cases is not less effective. This is a way of creation of conditions for selfdevelopment, elimination of obstacles and barriers, "inclusion of interests and incentives" for entrepreneurs in a recreational system itself. On this way what is important is to eliminate obstacles, institutional traps, excessive interdictions, disturbances, in other words, to provide a higher level of freedom for the demonstration of initiative and activeness in a team of all interested parties.

The first way is "of resource and innovation", and the second one is "institutional and managerial". Of course, the greatest success in development provides a reasonable combination and unification of these two paths, two vectors of influence on the recreational system - centralized and entrepreneurial. Such a combination (integration) should be provided by a relevant management mechanism - recreational management. Its basics are represented in Figure 3.

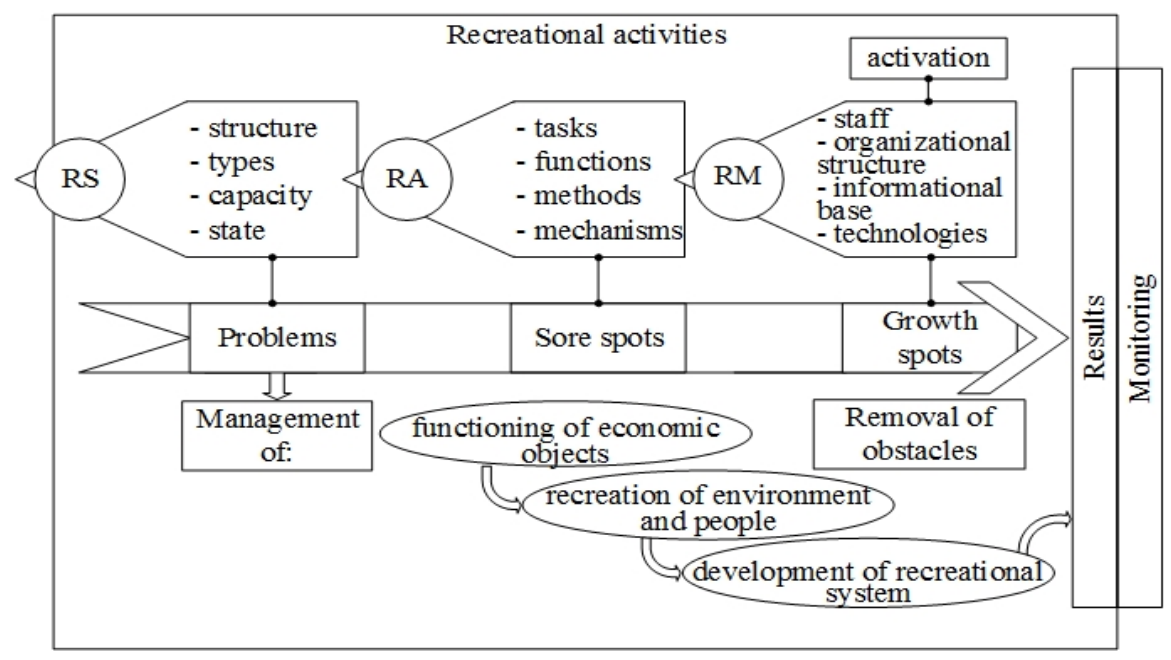

Figure 3. Recreation management as a special function of a recreational system 
The logic of building a model RS $=>\mathrm{RA}=>\mathrm{RM}$ is that the study of a recreational system (RS) makes no sense if no recreation activities (RA) are realized there, and recreational activities cannot be effective without recreation management (RM). The recreation management itself sets an objective to identify problems, highlight "sore spots" and transform all or some of them in "growth spots" using two different methods: activation of mechanisms of development and elimination of barriers.

From this point of view, it is necessary to identify the types of economic activity that are most pass in the scope of recreational services.

\section{Findings}

The field of recreational services is connected with tourism and hospitality complex (THC). In a fairly reasonable approximation, tourists can be considered as recreationists. In Ukraine, the number of tourists overtime is constantly growing ( $2-5 \%$ per year), and in 2017 the statistics show 24.6 million of our citizens travelling abroad and 14.2 million foreigners visiting Ukraine (State Statistics Service. Tourist flows, 2000-2017). In the volume of turnover in tourism the part of internal tourism (0.476 million people (State Statistics Service. Tourist flows, 2000-2017)) seems to be quite moderate, which must draw more attention of relevant authorities to tourism and recreation, in particular for their own citizens and on their territory. Of course, it is a positive trend that the Ukrainians want to "see the world", but it is more beneficial economically and socially to go on holiday, get new experience, and recreate on our own territory and use our own recreational capacity. And, it is becoming a nationwide scale problem the solution of which is able to contribute significantly to the development of a country in general.

The solution to this problem may be considered in several aspects:

-in the aspect of public recreational policy (the support of regions in their independent programmes of vacation and recreation realization on their own territory takes a special place in this policy);

- in the aspect of complexity and quality of tourism and recreation product, improving it to the international standards;

- in the aspect of achieving high rates of economic efficiency of enterprises and organizations providing recreational services, which will be an incentive for the inflow of investments in the industry, including foreign ones.

Nowadays, in tourism recreation and hospitality sector of Ukraine the situation is quite difficult: the low capacity and quality level of accommodation types, high level of pollution of nature and landscape environment, underdevelopment of infrastructure (transport, roads, utilities, retail chains), underdevelopment of recreational centres in comparison to an international level, insufficient level of development of excursion services. The above-mentioned drawbacks should also be considered as "sore spots" of tourism and recreation system of Ukraine. These "sore spots" if being sanitized can be transformed into growth spots which will guarantee recreation capacity building.

Recreation potential of a region has a complex structure which includes such components as sectorial capacities namely nature and resource, consumer, economic, infrastructure, competitive, investment, recreational. It is not a full list because there are many other "candidates for inclusion" into a recreational potential, but it represents a topic for a separate study. For instance, if there is a task to study the mechanisms of recreation system development the structure of potential should include such its components as innovative, informational, organizational and economic ones. In our research, the substantial, sense bearing part of recreational potential has great importance, i.e. volume, power, possibility, ability, cost. As to ability, it is considered as a resource for meeting needs. The difference between "possibility" and "practical use" is considered as a potential reserve or unused share of potential. One more comment: potential is not a strictly fixed quantity, it differs depending on the objectives of use, the content of structure elements, time factor (Figure 4).

Examining recreational systems from the perspective of a demand by recreationists and their ability to compete with each other, we draw a conclusion that competitiveness potential is more important and substantial not because of its integral estimation but because of the estimation of its individual components because these certain characteristics influence on a choice of a recreationist (roads, distances, landscape, places of interest, ecological situation, package, and type of recreational services). That is why we believe that the competitiveness potential is not a clearly defined internal quantity of recreation territory or recreational system: it has different importance depending on possibilities, preferences, and needs of recreationists. And not recreationists in general, but their certain groups and sectors. But the recreational value of a territory can be integrally estimated as its economic potential and "conditional recreational cost". In this case, the region's competitiveness in its recreational sector can be represented by the equation:

$$
K C_{p}=f_{n}\left(K P_{i}+K M\right) V_{p},
$$

where: $K C_{p}$ - recreational competitiveness (potential) of the region; $K P_{i}-$ a group of priorities of a recreational system typical for this very region; $K M$ - competitive management (level of its development); $V_{p}$ - dynamics of improvement of the recreational system (can be given by a modification coefficient, annual index). 

strategic goals of its usage and building

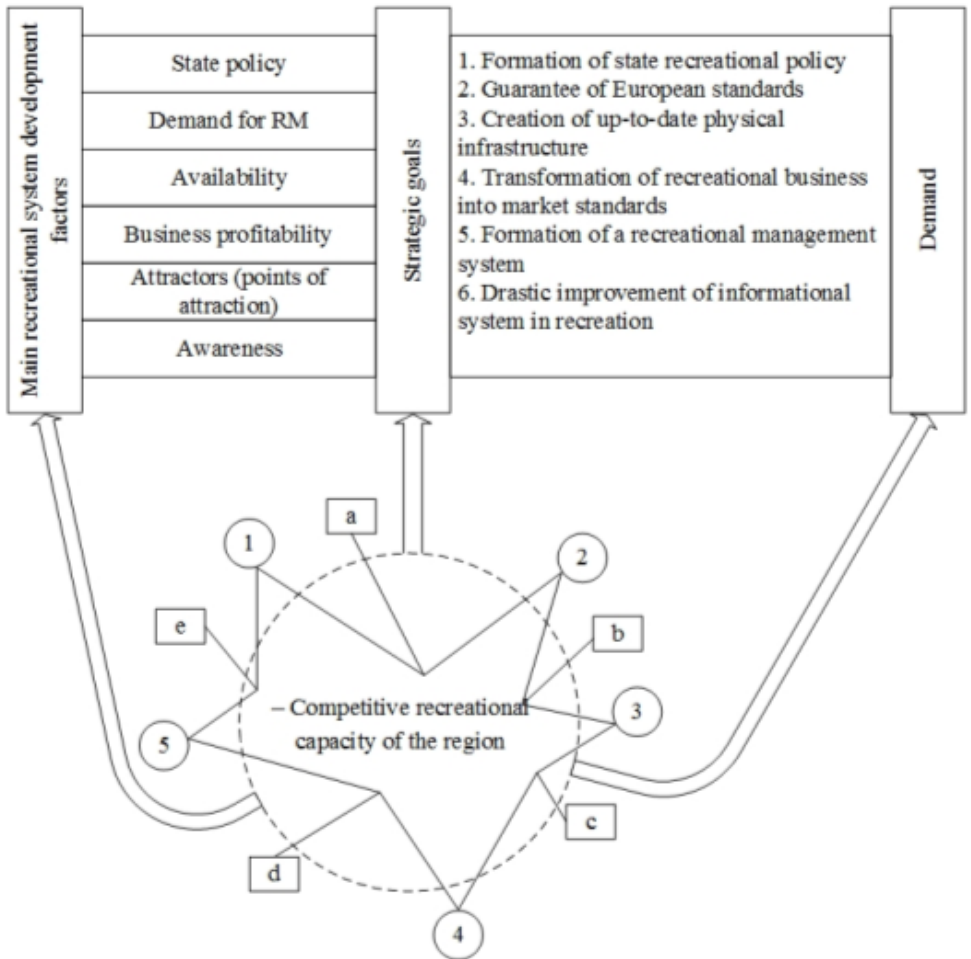

$\begin{array}{ll} & --- \text { integral estimation of degree of competitiveness } \\ \text { a - ecological situation } & 1 \text { - nature and landscape level } \\ \text { b - quality of service } & 2-\text { recreational complex } \\ c \text { - transport system } & 3 \text { - infrastructure } \\ \text { d-safety } & 4 \text { - historic and cultuaral attractors } \\ \text { e - compliance with international standarts } & 5 \text { - national characteristics }\end{array}$

Figure 4. Correlation between strategies of recreation system development and estimation of recreational competitiveness of the region

Our model (formal record) describes the fact that recreational competitiveness, except resource part which can be defined in, $K P_{i}$ has also another component - managerial $(\mathrm{KM})$, which provides for the use and development of this resource, which means that the potential is of the nature of the threefold integrity - "resource - mechanism - need of a recreationist", and being measured separately (as a resource) in isolation from other parts it does not reflect all social and economic nature where supply and demand are closely interrelated.

\section{Conclusions}

In the recreation services market competition is growing more and more, therefore the regions pay more attention to studying their potential, the needs of tourists, and options for creating a flexible model of managing a recreational system.

On the basis of the presented developments, it can be noted that in the regions, it is first of all necessary to lead recreational competitiveness, holistically consider the "resource-mechanism-recreant", based on which one can measure the socio-economic balance between supply and demand.

The results of the research show that in the development of the recreational system it is necessary to take into account not only the interests of the recreants but also the recreational environment, taking care to prevent damage and take measures to restore it. It is recommended to use the proposed mechanism of balanced joint development of human health and the recreational system.

The authors proposed to allocate recreational management to a special function of managing the development of the recreational system, which will reveal the problems and "sore points" of recreation, find ways to turn some of them into "growth points". It was proposed to use two different methods: activation of the mechanisms of development and elimination of barriers, which, in turn, may be included in the regional recreational policy of Ukraine.

It is also necessary to separately note a number of novelty elements of this research.

1. The study examines the duality of a person, a group and society, which is manifested in the fact that in a certain territory this active element of the socio-natural environment at the same time is the creator of the recreational system and its consumer. Duality is also manifested in the functional role of the recreational 
environment: it, on the one hand, performs the function of improving a person, and on the other hand, requires attention and expenditure from the person and society to save and improve: the recreational environment itself needs to be "improved".

2. Society and nature in their relationship are interrelated and interdependent. And when the anthropogenic load on the environment is minimal or permissible, the process of such relations can occur spontaneously, unregulated. With large anthropogenic loads on the environment, the need to manage and regulate these relations is already coming to the fore. At the same time, it is necessary to ascertain the fact that recreational management in Ukraine is practically not developed and not mastered in order to perform such functions. In the study are presented the features of the system mechanism of the function of recreational management, among which are such components as the definition of recreational potential, the assessment of "sore points of the system", the practice of parameter setting, the balance of administrative and market regulators.

3. Two different paths of development of the recreational system are highlighted: direct - directive increase in investments in development activities, programming of positive changes; indirect - the creation of conditions for self-development of territories and recreational systems on it, the removal of barriers and the use of incentives. The optimal development model is a reasonable combination of these two ways of ensuring the development of the recreational system.

4. An important element of the novelty is the reasoned view of the recreational potential as a non-fixed, ambiguously measured value. This potential, depending on the objectives of its use and the quality of internal elements, can be represented in different dimensions and assessments, including such as value and competitiveness. It is proposed a conceptual model for assessing the competitiveness of a region in its recreational sector. A feature of this model is the inclusion of recreational management as an activator of the use of recreational resources. This management solves the dual problem: it increases the economic efficiency of the recreational system and improves and strengthens the health resource of the recreants.

\section{References}

112.UA. (2016). The area of landfills in Ukraine is 7\% of the entire territory. Retrieved from https://ua.112.ua/suspilstvo/ploshcha-smittiezvalyshch-v-ukraini-stanovyt-7-vid-usiiei-terytorii-sauk-338008.html

Bulysheva, D., \& Andreev, N. (2018). Ecologization of economic relations in the system of recreational land use of urban agglomerations: theory and practice. Odessa: Ipride NASU.

Dobush, J. (2013). Estimation of the level of development of natural resource potential of balneological resorts. Marketing and Innovation Management, 4, 326-337.

Dutchak, S. (2014). Tourist and recreational resources of landscapes. Chernivtsi: Publishing House Rodovid. Fomenko, N. (2007). Recreational resources and health resort. Kiev: Center for Educational Literature.

Gaman, P. (2008). Development of the recreational sphere of the Carpathian region of Ukraine: the theory and practice of state regulation. Donetsk: South-East Ltd.

Gerasimenko, V., Bedradina, G., Galasyuk, S., et al. (2016). Estimation of the tourist-recreational potential of the region. Odessa: ONEU.

Hall, C. M., \& Page, S. (2006). The geography of tourism and recreation: environment, place and space (3rd ed.). Abingdon, Oxon, New York, NY: Routledge. https://doi.org/10.4324/9780203420249

Informator. (2017). It became known how the ecological situation in Ukraine over the past decade has changed. Retrieved from https://informator.news/stalo-vidomo-yak-zminylasya-ekolohichna-sytuatsiya-v-ukrajini-za-ostannje-desyatyrichchya/

Karyi, O. (2015). Transformation of a city dweller into the city in the process of strategic planning of city development. Marketing and Innovation Management, 1, 32-44. Retrieved from https://mmi.fem.sumdu.edu.ua/journals/2015/1/32-44

Kilinskaya, K., Anipko, N., Konovalova, N., Andrusyak, N., et al. (2010). Theoretical and applied aspects of nature recreation in Ukraine. Chernivtsi: Chernivtsi National University.

Kishor, M. (2019). Top 10 most visited countries in the world 2018. Retrieved from https://earthnworld.com/top-10-mostvisited-countries-in-the-world/

Local Government NSW. (n.d.). Tourism. Retrieved from https://www.lgnsw.org.au/policy/tourism\#main-content

Maister, S., \& Dombrovskaya, S. (2017). Features of public administration of recreational tourism of Ukraine. Kharkiv.

Pavlova, J. (2016). Recreational and recreational technologies and quality of human life. Lviv: LDUFK.

Poida-Nosyk, N., \& Grabar, M. (2016). System development of tourism and recreation: theoretical and practical aspects of management at the regional level. Uzhgorod: View of UzhNU "Goverla".

Pokolodna, M., \& Polchaninova, I. (2012). Summary of lectures on discipline "Recreational complexes of the world (including touristic resources of Ukraine)". Kharkiv.

Polchaninova, I., \& Ignatova, N. (2011). The optimization of the process of choosing sources of financing for the tourist and recreational complex of the Kharkiv region, using the theory of decision-making. The Bulletin of the Khmelnytsky National University. Economic Sciences, 3(5), 243-247. 
Ryabev, A.; Balandina, I.; Polchaninova, I.; Obolentseva, L. 2019. Recreation capacity of Ukraine's regions, strategic goals of its usage and building

Polchaninova, I., \& Perederij, M. (2015). Analysis of factors of development of sanatorium and resort enterprises of Kharkiv region. International Scientific Journal: Collection of Scientific Works, 8, 61-73.

Polchaninova, I., \& Tamchy, A. (2016). Theoretical fundamentals of management of the development of the territorial recreational complex. International Scientific Journal: Collection of Scientific Works, 11(2), 86-97.

Ryabev, A., \& Balandina, I. (2017). An analysis of the current state and prospects of camping development in the Kharkiv region. In Problems and prospects of entrepreneurship development: Collection of scientific works of the Kharkiv National Automobile and Road University (Vol. 1, pp. 97-103). Kharkiv: KhNADU. Retrieved from https://fmab.khadi.kharkov.ua/fileadmin/ F_Management_Business/ek_predpriyatiy/Publications/n_3_18_1_2017.pdf

Stafiichuk, V. (2008). Recrealogy (2 $2^{\text {nd }}$ ed.). Kyiv: Alt Press.

State Statistics Service. Tourist flows. (2000-2017). Retrieved from https://www.ukrstat.gov.ua/operativ/operativ2007/ tyr/tyr_u/ potoki2006_u.htm

Stupen, N. (2017). Areas of increase of investment attractiveness of recreational territories. Balanced Nature Using, 7(3), 6369. Retrieved from http://natureus.org.ua/repec/archive/3_2017/12.pdf

UNEP and UNWTO. (2005). Making tourism more sustainable - a guide for policy makers. Retrieved from http://www.unep.fr/shared/publications/pdf/dtix0592xpa-tourismpolicyen.pdf

UNWTO. (2017). UNWTO tourism highlights. Retrieved from http://www2.unwto.org/publication/unwto-tourism-highlights2017 